\title{
ANALISIS OPINI LAPORAN HASIL PEMERIKSAAN BPK RI (STUDI PADA BADAN KEAMANAN LAUT RI)
}

\author{
Sudarman Damanik \\ Elvia Rosantina Shauki \\ Universitas Indonesia \\ Alamat Korespondensi: sudarman.damanik@ui.ac.id
}

\begin{abstract}
This study aims to explore the phenomena and analyze factors that cause disclaimer opinion (TMP) from the Indonesian Supreme Audit Board (BPK) on the financial statements of the Indonesian Coast Guard (Bakamla) for the 2016-2018 period, as well as providing the rule of determination in improving Bakamla's financial statements quality towards a Fair Opinion without Exception (WTP) opinion. Bakamla is the only Ministry / Institution in which financial report receives TMP opinion for Fiscal Year 2018. This study uses a theoretical framework in the form of Institutional logics and Isomorphism, where the organizational field used in this study is Bakamla. The findings show that from the symbolic carrier aspects, there are National regulations (Law, PP, PMK, and BPK) allowing Bakamla to further regulate the uniqueness of the institution (in terms of finance and assets). Meanwhile, the International Regulations (IPSAS) were still not mandatory rules, meaning that Bakamla has not followed the regulations issued by IPSAS. By Institutional logic, it was found that the regulations issued by the Ministry of Finance and BPK were not implemented optimally (decoupled), where actors prefer to use material carriers in preparing their financial statements. Actors apply the cultures and the routines of the original parent in terms of reporting financial and asset aspects (routines, procedures, and artifacts). The existing organizational structure still needs to be improved in responding to the uniqueness of Bakamla; this has become an obstacle in achieving WTP opinion.
\end{abstract}

\section{KATA KUNCI:}

Teori istitusional (Institutional Theory), Logika Institusional (Institutional logics), Isomorphism, Badan Keamanan Laut Republik Indonesia (Bakamla), Coupling, Decoupling, Opini Audit

\begin{abstract}
ABSTRAK
Penelitian ini bertujuan untuk menggali fenomena dan menganalisis hal-hal yang menyebabkan opini Tidak Memberikan Pendapat (TMP) dari Badan Pemeriksa Keuangan (BPK) RI terhadap laporan keuangan Badan Keamanan Laut (Bakamla) untuk periode 2016-2018, serta memberikan rule determination dalam peningkatan kualitas laporan keuangan Bakamla menuju opini Wajar Tanpa Pengecualian (WTP). Bakamla merupakan satu-satunya Kementerian/Lembaga yang laporan keuangannya mendapat opini TMP untuk Tahun Anggaran 2018. Studi ini menggunakan kerangka teori berupa Institutional Logics dan Isomorphism di mana organizational field yang digunakan adalah Bakamla. Hasil temuan menunjukkan dari aspek symbolic carriers, terdapat peraturan-peraturan Nasional (UU, PP, PMK, dan BPK) membolehkan Bakamla untuk mengatur lebih lanjut mengenai keunikan lembaga (dalam hal keuangan dan asset). Sementara itu, Peraturan Internasional (IPSAS) masih belum merupakan aturan mandatory, dimana Bakamla belum mengikuti peraturan yang dikeluarkan oleh IPSAS (non-mandatory). Berdasarkan teori Institutional logics ditemukan bahwa peraturan yang dikeluarkan oleh Kementrian Keuangan dan BPK belum dijalankan secara optimal (decoupled) sehingga aktor lebih memilih menggunakan material carries dalam penyusunan Laporan keuangannya. Dari aspek material carriers, aktor menggunakan budaya dan rutinitas induk semula dalam hal pelaporan aspek keuangan dan asset (routines, procedures, dan artefacts). Struktur organisasi yang ada masih belum sempurna menyikapi keunikan Bakamla, hal ini menjadi kendala untuk pencapaian opini WTP.
\end{abstract}

\section{KLASIFIKASI JEL:}

M420

CARA MENGUTIP:

Damanik, S. \& Shauki, E. R. (2019). Analisis opini laporan hasil pemeriksaan bpk ri (studi kasus pada badan keamanan laut ri). Indonesian Treasury Review: Jurnal Perbendaharaan, Keuangan Negara dan Kebijakan Publik, 4(4), 385-402. 


\section{PENDAHULUAN}

\subsection{Latar Belakang}

Pemerintah memiliki kewajiban untuk menyampaikan informasi terkait keuangan sebagai dasar pengambil keputusan oleh pemangku kebijakan. Laporan keuangan Pemerintah yang baik dan memadai salah satunya dapat diindikasikan dengan pemberian opini Wajar Tanpa Pengecualian (WTP) oleh Badan Pemeriksa Keuangan (BPK) RI atas laporan keuangan terperiksa. Berdasarkan amanat UU Nomor 15 Tahun 2004 tentang Pemeriksaan Pengelolaan dan Tanggung Jawab Keuangan Negara Pasal 3, BPK dapat melakukan pemeriksaan pengelolaan dan tanggung jawab keuangan negara meliputi seluruh unsur Keuangan Negara (RI, 2004)

Pemeriksaan keuangan bertujuan untuk memberikan keyakinan yang memadai (reasonable assurance) apakah laporan keuangan telah disajikan secara wajar, dalam semua hal yang material sesuai dengan prinsip akuntansi yang berlaku umum di Indonesia atau basis akuntansi komprehensif selain prinsip akuntansi yang berlaku umum di Indonesia.

Pemeriksa memberikan opini atas laporan keuangan yang diperiksa. Opini merupakan pernyataan profesional pemeriksa mengenai kewajaran informasi keuangan yang disajikan dalam laporan keuangan yg didasarkan pada kriteria: 1) kesesuaian dengan SAP (PP 71/2010); 2) kecukupan pengungkapan (adequate disclosures); 3) kepatuhan terhadap peraturan perundang-undangan; dan 4) efektivitas Sistem Pengendalian Internal. Terdapat 4 (empat) jenis opini yg dapat diberikan oleh pemeriksa, yakni: (i) wajar tanpa pengecualian (unqualified opinion), (ii) wajar dengan pengecualian (qualified opinion), (iii) tidak wajar (adversed opinion), dan (iv) pernyataan menolak memberikan opini (disclaimer of opinion) (Kuntadi, 2019).

Badan Keamanan Laut Republik Indonesia didirikan berdasarkan UU No. 32 tahun 2014 tentang Kelautan dan Peraturan Presiden No.178 Tahun 2014 tentang Badan Keamanan Laut. Bakamla mempunyai tugas melakukan patroli keamanan dan keselamatan di wilayah perairan Indonesia dan wilayah yurisdiksi Indonesia (BPK, 2019). Badan Keamanan Laut RI termasuk salah satu dari Kementerian/Lembaga yang memperoleh opini TMP atas Laporan Keuangan Tahun Anggaran 2016, 2017 dan 2018.

Berdasarkan Laporan Hasil Pemeriksaan BPK, akar permasalahan atas laporan keuangan Bakamla untuk Tahun Anggaran 2018 yang menyebabkan Bakamla mendapat opini tidak menyatakan pendapat adalah sebagai berikut:
1. Pengujian atas saldo persediaan tahun 2018 menunjukkan terdapat persediaan sebesar Rp3,66 miliar yang disajikan tidak berdasarkan hasil inventarisasi fisik (stock opname) akhir tahun. BPK menemukan ketidakpatuhan terhadap peraturan perundang-undangan, yaitu (a) hasil pengadaan satellite monitoring diantaranya sebesar Rp22,23 miliar tidak dapat dirinci sesuai jenis barang dan harganya, (b) permasalahan nilai belanja dibayar sebesar Rp.87,25 miliar yang tidak terealisasi sampai dengan akhir tahun 2018, (c) ketidakpastian dampak proses hukum oleh KPK dan Aparat Penegak Hukum lainnya yang masih berlangsung, serta (d) KDP yang tidak dapat dirinci sesuai jenis barang dan harganya, akibatnya BPK tidak dapat melakukan penilaian atas kewajaran saldo Belanja Dibayar Dimuka dari KDP (BPK,2019).

2. Pengujian atas saldo Aset Tetap Peralatan dan Mesin Tahun 2018 menunjukkan terdapat Aset Tetap Peralatan dan Mesin sebesar Rp.57,55 miliar yang berasal dari alih status aset Kementerian Koordinator Politik, Hukum dan Keamanan belum jelas keberadaannya (BPK, 2019).

3. Realisasi Belanja Barang sebesar Rp7,12 miliar tidak dilaksanakan sesuai ketentuan (BPK, 2019).

\subsection{Rumusan Masalah}

Berdasarkan latar belakang penelitian tersebut, perumusan masalah dalam penelitian ini adalah sebagai berikut.

1. Bagaimana dengan tingkat kesamaan Bakamla dan institusi-institusi lainnya dalam pengungkapan LK dan apakah ada logika dominan yang menyeluruh (an overarching dominant logic)? Secara rinci, pertanyaan ini ditetapkan untuk menjawab:

a. Sejauh mana Bakamla menerapkan dan memenuhi semua persyaratan pembawa simbolik (symbolic carriers)?

b. Sejauh mana pengaruh faktor lokal terhadap praktik pelaporan keuangan di Bakamla?

c. Apakah ada satu atau banyak logika pelaporan LK yang dilakukan oleh Bakamla?

2. Bagaimana dengan faktor institusional, manakah yang memfasilitasi atau mencegah pembawa materi (material carriers) praktik dipisahkan dari pembawa simbolik (symbolic carriers)?

3. Bagaimana dengan tingkat kesamaan Bakamla dan institusi-institusi lainnya atas tekanan-tekanan isomorfis/proses penyelarasan baik yang berasal dari dalam maupun luar institusi (mimetic isomorphism, 
coercive isomorphism, atau normative isomporphism)?

\subsection{Tujuan Penelitian}

Penelitian ini dilakukan untuk mencapai tujuan sebagai berikut:

a. Mengidentifikasi tingkat kesamaan Bakamla dan institusi-institusi lainnya dalam pengungkapan LK dan logika dominan yang menyeluruh (an overarching dominant logic);

b. Menganalisis faktor institusional, manakah yang memfasilitasi atau mencegah pembawa materi (material carriers) praktik dipisahkan dari pembawa simbolik (symbolic carriers);

c. Menganalisis tingkat kesamaan Bakamla dan institusi-institusi lainnya atas tekanantekanan isomorfis baik yang berasal dari dalam maupun luar institusi (mimetic isomorphism, coercive isomorphism, atau normative isomporphism).

\subsection{Kontribusi Penelitian}

Hasil penelitian ini diharapkan dapat memberikan manfaat antara lain:

a. Bagi Bakamla dan regulators: memberikan rule determinations berupa perbaikan Standard Operating Procedures (SOP) dan/atau pembuatan SOP baru untuk meningkatkan kualitas laporan keuangan Bakamla menuju opini WTP.

b. Bagi akademisi: menjadi dokumen akademik yang bermanfaat sebagai referensi bagi penelitian selanjutnya mengenai respons pelaksana dan manajer (yang bertindak sebagai aktor) keuangan dalam menghadapi masalah penyajian laporan keuangan.

c. Bagi Instansti Pemerintah Pusat/Daerah: menjadi contoh model terbaik dalam menelusuri masalah laporan keuangan yang terjadi dalam suatu organisasi khususnya pengaplikasian teori dan rule determinations sebagai luaran dari studi kasus yang digunakan dalam penelitian ini.

\section{STUDI KEPUSTAKAAN}

\subsection{Penelitian Terdahulu}

(Robu dan Robu, 2015) menganalisis pengaruh laporan audit, disiapkan untuk laporan keuangan 59 perusahaan yang terdaftar di Bursa Efek Bucharest (BSE) Romania selama periode pelaporan 2012, kepada investor di pasar keuangan tentang akuisisi atau penjualan saham. Terdapat perbedaan antara penelitian yang dilakukan oleh Robu dan Robu dengan penelitian ini, yaitu unit analisis dan teknik analisis data. Studi ini meneliti alasan dari para aktor yang menyebabkan laporan keuangan Bakamla periode 2016-2018 mendapat opini TMP dari BPK RI dengan menggunakan logika institusional (institutional logics) dan Isomorphism sedangkan Robu dan Robu menjadikan 59 perusahaan yang terdaftar di Bursa Efek Bucharest (BSE) selama periode pelaporan 2012 sebagai unit analisisnya dengan teknik analisis regresi ANOVA.

Aldemir dan Uysal (2017) menjelaskan perkembangan sistem akuntansi publik di Turki dengan bantuan teori institusional. Aldemir dan Uysal menjelaskan semua dinamika yang menyediakan pelembagaan akun negara dalam arti nasional, bersama dengan proses ekonomi, politik dan sosial dari periode yang bersangkutan. Pengaturan peraturan secara langsung berkontribusi pada pelembagaan dari suatu bidang, dan sebagai hasilnya, bagaimana organisasi publik secara langsung berkontribusi pada proses pelembagaan. Terdapat perbedaan antara penelitian yang dilakukan oleh Aldemir dan Uysal dengan penelitian ini, yaitu unit analisisnya. Studi ini meneliti alasan dari para aktor (unit analisis) yang menyebabkan laporan keuangan Bakamla periode 2016-2018 mendapat opini TMP dari BPK RI sedangkan Aldemir dan Uysal menjadikan transformasi aturan akuntansi publik antara tahun 1800 dan 1950 sebagai unit analisisnya.

Moghaddam et al. (2016) menguji jumlah hubungan antara opini audit yang memenuhi syarat dengan informasi penting tentang kualitas audit perusahaan, dan menguji peran opini audit dalam mensinyalkan pendapatan 123 perusahaan yang terdaftar di Bursa Efek Teheran selama 2009 hingga 2013. Moghaddam et al (2016) menggunakan teknik analisis regresi multivariat, model data Panel, dan metode Estimasi Generalized Least Squares (EGLS). Terdapat perbedaan antara penelitian yang dilakukan oleh Moghaddam, et al. dengan penelitian ini, yaitu unit analisisnya dan teknik analisisnya

Carpeter dan Feroz (2001) menjelaskan bagaimana tekanan institusional yang diberikan kepada pemerintah pusat di empat wilayah yaitu New York, Michigan, Ohio, dan Delaware berpengaruh pada keputusan pemerintah untuk mengadopsi kegunaan Generally Accepted Accounting Principles (GAAP) dalam laporan keuangan eksternal. Terdapat perbedaan antara penelitian yang dilakukan oleh Carpeter dan Feroz dengan penelitian ini, yaitu unit analisisnya. Studi ini meneliti alasan dari para actor (unit analisis) yang menyebabkan laporan keuangan Bakamla periode 2016-2018 mendapat opini TMP dari BPK RI sedangkan Carpeter dan Feroz menjadikan pemerintah New York, Michigan, Ohio, dan Delaware sebagai unit analisisnya.

Dengan melihat dan membandingkan dengan penelitian-penelitian sebelumnya, 
peneliti berharap agar hasil analisis yang didapatkan merupakan perluasan usulan dari penelitian sebelumnya yang dapat diterapkan oleh pihak Bakamla untuk menuju opini WTP yang diharapkan. Institutional logics dan Isomorphism sangat tepat digunakan untuk menyelesaikan permasalahan dalam penelitian ini. Dengan pendekatan studi kasus dapat menghasilkan rule determinations yang dapat memberikan manfaat, khususnya kepada Bakamla, agar dapat memperbaiki opini laporan keuangan menjadi opini WTP, dan umumnya menjadi referensi untuk kementerian/lembaga lain yang membutuhkan.

\subsection{Institutional logics dan Isomorphism}

New Institutional Theory digunakan pada penelitian ini dengan mengaplikasikan instistutional logics dan isomorphisms. Institutional theory menjelaskan bagaimana dan mengapa aktor dalam organisasi yang terbentuk dan tertanam oleh struktur kelembagaan menjadi termotivasi dan memungkinkan untuk mendorong perubahan dalam struktur tersebut (Lawrence, Suddaby, dan Leca, 2011); (Greenwood dan Suddaby, 2006); (DiMaggio dan Powell, 1983). Oleh karena itu, menganalisis peran aktor dalam organisasi sangat penting dalam meninjau implementasi institutional theory.

Di dalam teori institusional, dikenal istilah bidang organisasi (organizational field). Bidang organisasi didefinisikan sebagai, "By organizational field, we mean those organizations that, in the aggregate, constitute a recognized area of institutional life: key suppliers, resource and product costumers, regulatory agencies, and other organizations that produce similar services or products" (DiMaggio dan Powell, 1983, p. 148). Berkenaan dengan fenomena konvergensi dalam implementasi standar internasional, institutional theory dapat digunakan sebagai salah satu alat untuk menganalisis fenomena tersebut dengan menggunakan Bakamla yang menyajikan laporan keuangan sebagai organizational field-nya.

Selanjutnya (Zilber, 2013) menyampaikan bahwa penggunaan institutional logics diakui telah memberikan pemahaman yang lebih mengenai sifat dari struktur, bagaimana mereka mapan, dan sampai sejauh mana perbedaan tingkat kelembagaan mempengaruhi persepsi dan perilaku dari para aktor. Institutional logics sebagaimana dikemukakan oleh (Scott, 1987) sebagai perangkat sistem kognitif dan normatif yang berbeda dan terspesialisasi telah menjadi buzzword dalam penelitian kelembagaan.

Logics merupakan bagian dari new institutional theory yang penting karena membantu untuk menjelaskan hubungan yang menciptakan rasa akan kesamaan tujuan dan kesatuan dalam suatu bidang organisasi (Reay dan Hinings, 2009). Logics inilah yang nantinya akan mempengaruhi para aktor dalam organisasi dalam bertindak. Institutional logics. Menurut Zilber (2013), institutional logics terdiri dari empat prinsip utama, yaitu: (1) berusaha mengintegrasikan agensi dan struktur, (2) mengintegrasikan antara material dan simbolis, (3) memperhatikan kemungkinan historis dari institusi, dan (4) mengikuti institusi di berbagai tingkat sosial. Kunci utama dari analisis institusional adalah untuk memahami hubungan antara logics dan perubahan institusional dan sebaliknya untuk memahami bagaimana dan kapan logics tersebut akan bergeser (Gawer dan Philips, 2013).

Konsep lain terkait dengan new institutional theory adalah isomorphism atau proses penyelarasan atas suatu organisasi dengan organisasi lainnya (Oliver, 1991); (DiMaggio dan Powell, 1983). Terdapat dua jenis isomorphism menurut DiMaggio dan Powell (1983), yaitu (1) competitive isomorphism, yaitu rasionalisasi yang menekankan pada kondisi persaingan yang terjadi, perubahan niche, dan ukuran kemampuan; dan (2) institutional isomorphism, yang mempertimbangkan faktorfaktor selain persaingan, seperti aspek politik dan legitimasi kelembagaan serta kondisi sosial dan ekonomi. Sementara itu, Oliver (1991) menyatakan bahwa semakin rendah tingkat keterkaitan organisasi dengan lingkungan kelembagaan, tingkat penghindaran dan manipulasi akan lebih cenderung terjadi pada organisasi tersebut. Terdapat tiga mekanisme yang dapat mengakibatkan munculnya perubahan dalam institutional isomorphism, yaitu:

a. Coercive, sebagai akibat dari masalah legitimasi berupa tekanan baik formal ataupun informal yang diberikan/dipaksakan kepada organisasi oleh pemerintah atau organisasi lain. Tekanan formal didapatkan organisasi dari peraturan dan standar seperti undangundang, peraturan pemerintah, dan SOP. Tekanan informal didapatkan organisasi dari lingkungan luar yang dijadikan patokan oleh organisasi agar dapat diterima secara administrative dan budaya dalam masyarakat (DiMaggio dan Powell, 1991); (Greenwood dan Suddaby, 2006);

b. Mimetic, sebagai tanggapan atas ketidakpastian baik dalam hal tujuan maupun lingkungan beroperasi sehingga organisasi melakukan imitasi terhadap organisasi lainnya (mencari contoh model terbaik dari organisasi yag sukses) baik disadari maupun tidak disadari dengan 
tujuan melindungi organisasi dari ketidakpastian (DiMaggio dan Powell, 1983); (Oliver, 1991); dan

c. Normative, berkaitan dengan profesionalisme, yaitu salah satu upaya untuk menetapkan dasar kognitif dan legitimasi untuk otonomi pekerjaan mereka melalui dua mekanisme yaitu melalui jalur pendidikan formal dan hasil penelitian tenaga ahli yang memiliki kewenangan, dan melalui jaringan profesional yang saling hal material sesuai Standar Akuntansi Pemerintah (SAP). Kriteria opini WTP antara lain: (1) Laporan keuangan sudah lengkap (terdiri atas laporan perhitungan anggaran, laporan arus kas, laporan laba rugi/neraca, laporan operasional, laporan perubahan ekuitas, dan catatan atas laporan keuangan); (2) Dokumen pendukung cukup lengkap; (3) Laporan keuangan telah disajikan sesuai Standar Akuntansi Pemerintah dan Pemakaian Standar yang konsisten; serta (4) Tidak ada kondisi yang

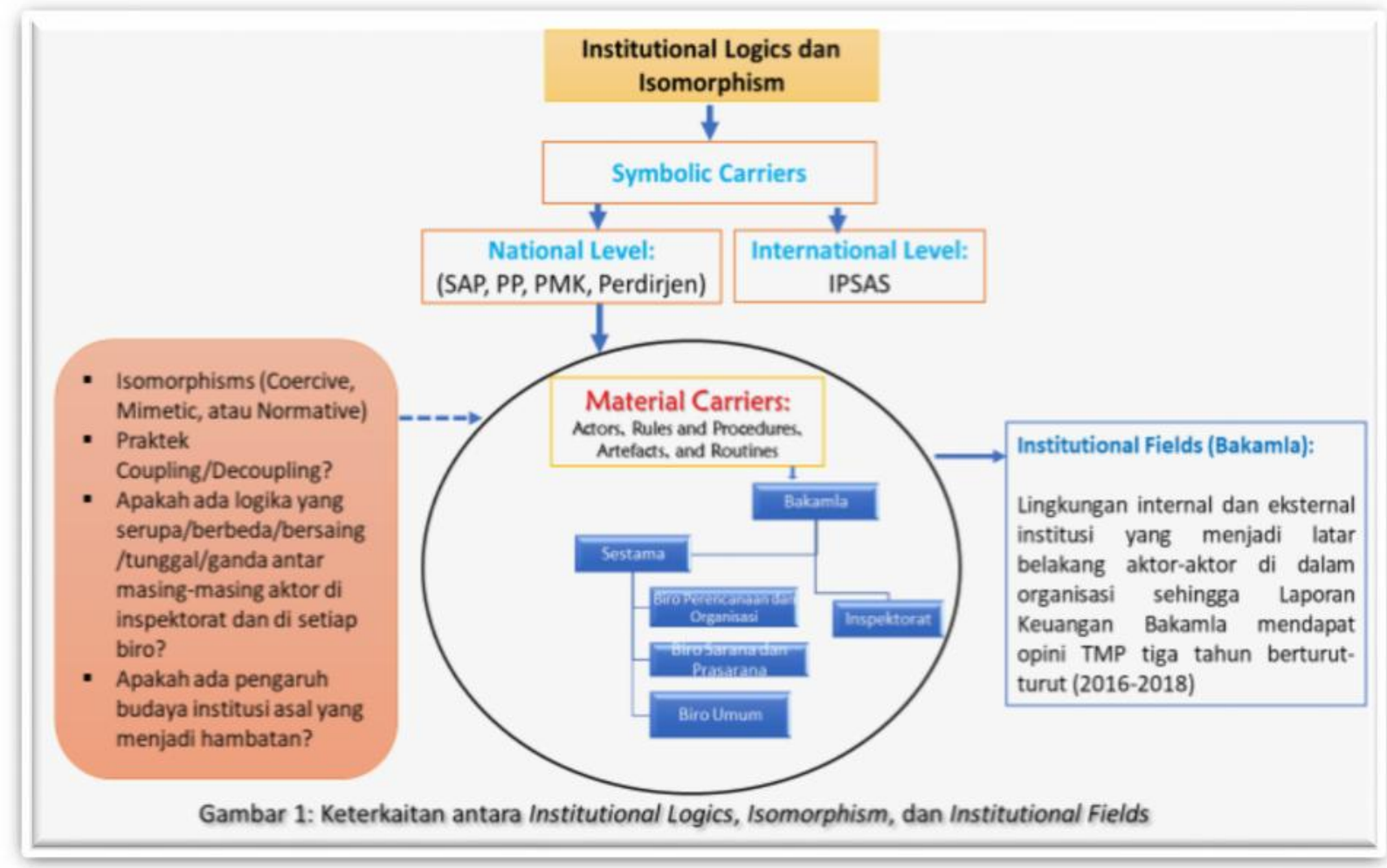

berbagi ilmu pengetahuan dan teknologi (DiMaggio dan Powell, 1983). Oliver (1991) menyebut proses ini sebagai compliance yang merupakan ketaatan untuk memasukkan nilai-nilai, norma, ataupun persyaratan institusional.

Keterkaitan antara organizational field, institutional logics, dan isomorphism sesuai permasalahan dalam penelitian ini sebagaimana telah dijelaskan di atas dapat dilihat pada Gambar 1.

\subsection{Opini Audit}

Berdasarkan Undang-undang Nomor 15 Tahun 2004, Kuntadi (2019 menjelaskan terdapat 4 (empat) jenis Opini yang diberikan oleh BPK RI atas Pemeriksaan atas Laporan Keuangan Pemerintah yaitu: pertama, Opini Wajar Tanpa Pengecualian (Unqualified Opinion) biasa disingkat WTP, merupakan opini tertinggi dari hasil pemeriksaan. Di sini pemeriksa berpendapat bahwa laporan keuangan yang diperiksa telah tersaji secara wajar dalam semua memerlukan paragraf penjelasan. Kedua, Opini Wajar Dengan Pengecualian (Qualified Opinion) atau "Wajar Dengan Pengecualian" biasa disingkat WDP, merupakan opini pemeriksaan ranking setelah WTP. Dalam hal ini pemeriksa berpendapat bahwa laporan keuangan telah menunjukkan laporan yang wajar, kecuali untuk komponen-komponen tertentu dengan kriteria. Sebagian laporan keuangan disusun tidak memenuhi standar akuntansi keuangan dan/atau ruang lingkup pemeriksaan dibatasi.

Ketiga, Opini Tidak Wajar (Adversed Opinion) yaitu opini audit yang diterbitkan jika laporan keuangan mengandung salah saji material karena tidak sesuai dengan Standar Akuntansi Pemerintahan, atau dengan kata lain laporan keuangan tidak mencerminkan keadaan yang sebenarnya; tidak memenuhi kaidah-kaidah yang seharusnya. Opini jenis ini menunjukkan bahwa laporan keuangan pemerintah diragukan kebenarannya, sehingga bisa menyesatkan pengguna laporan keuangan dalam pengambilan 
keputusan. Kriterianya adalah standar akuntansi tidak dipakai dan/atau adanya ketidakkonsistenan dalam menggunakan prinsip akuntansi.

Keempat, Pernyataan Menolak Memberikan Opini (Disclaimer of Opinion) atau "Tidak Memberikan Pendapat".

\subsection{Kerangka penelitian}

Teori yang digunakan dalam penelitian ini adalah New Institutional Theory untuk mengidentifikasi respon organisasi dan sikap para actor dalam organisasi dalam menghadapi masalah laporan keuangan.

Organizational field dalam penelitian ini adalah Bakamla yang didalamnya terdapat material carriers dan symbolic carriers seperti yang menangani pelaporan keuangan dan BMN Bakamla pada Inspektorat, Biro Sarana dan Prasarana, Biro Umum, dan Biro Perencanaan dan Organisasi.

\section{METODOLOGI PENELITIAN}

\subsection{Strategi Penelitian}

Penelitian ini dilakukan dengan menggunakan strategi berupa studi kasus. Pendekatan studi kasus digunakan untuk menjawab pertanyaan yang termasuk kategori pertanyaan "mengapa" dan "bagaimana", dengan menelusuri hubungan operasional yang saling terkait atas fenomena yang diteliti dari waktu ke waktu (Yin, 2003). Pendekatan studi kasus diharapkan dapat menjelaskan kerumitan masalah penelitian dengan suatu ketertarikan khusus dalam

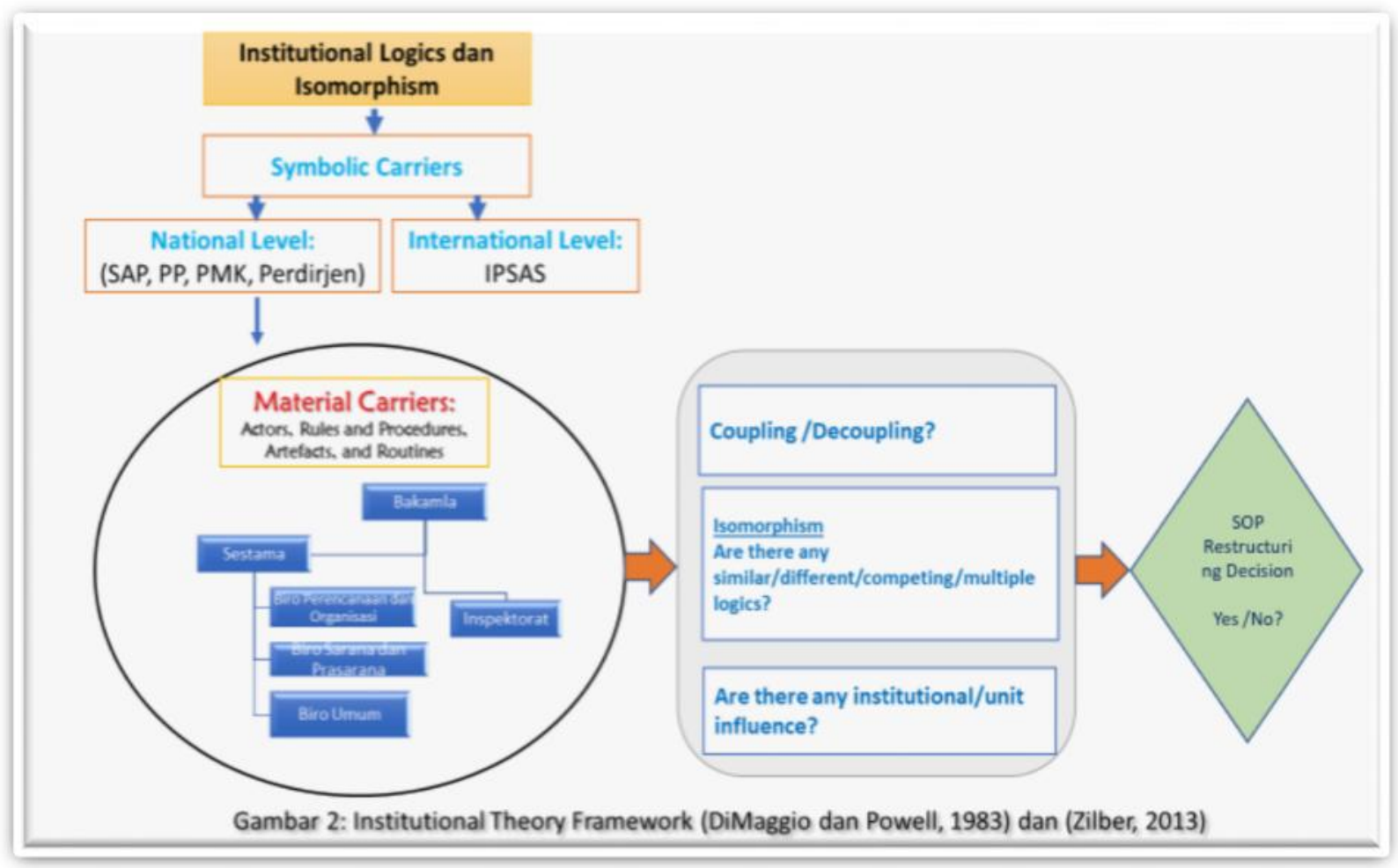

terlihat pada Gambar 2. Adapun hasil analisis data pada symbolic carriers yang didapatkan akan diolah untuk mendapatkan kesimpulan apakah terjadi couple/decouple menurut Institutional Theory dan apakah terdapat persamaan/tidak menurut teori Isomorphism. Setelah itu dapat diambil keputusan apakah peneliti akan membuat SOP atau memperbaiki SOP yang sudah ada.

Penelitian ini membahas mengenai identifikasi alasan yang menyebabkan laporan keuangan Bakamla periode 2016-2018 mendapat opini TMP dari BPK RI dan analisis tantangan yang diterima oleh Bakamla sehingga opini laporan keuangannya tidak ter-upgrade. Penelitian menggunakan wawancara terhadap unit analisis yaitu aktor keuangan yang menelitinya dengan menekankan keadaan, urutan kejadian dalam konteks, dan keutuhan individu (Stake, 1995).

\subsection{Pendekatan Penelitian}

Pendekatan penelitian ini berupa studi kualitatif untuk dapat memberikan penjelasan yang lebih mendalam (in-depth observation) mengenai fenomena permasalahan penelitian ini. Penggunaaan pendekatan kualitatif digunakan karena akan melakukan pengolahan data yang bersifat text-based mengenai permasalahan sosial. Hasil penelitian diharapkan menyediakan simpulan dari informasi yang selengkap mungkin mengenai laporan keuangan di lingkungan Bakamla. Peneliti berinteraksi dengan melakukan pengamatan langsung dan merasakan 
konseptual sehingga dapat memahami bagaimana makna yang berkaitan dengan pokok masalah penelitian.

\subsection{Pengumpulan Data \\ 3.3.1. Sumber Data}

Data yang dikumpulkan dalam penelitian ini terdiri dari data primer dan data sekunder. Data primer menurut Church (2001) merupakan data yang dikumpulkan secara langsung oleh peneliti kepada pihak terkait. Data primer dalam penelitian ini diperoleh melalui dokumentasi (yang tidak terpublikasikan) dan wawancara. Dokumentasi dilakukan terhadap SOP keuangan Bakamla. Sedangkan, wawancara dilakukan terhadap beberapa pihak yaitu: Biro Umum, Biro Perencanaan, Biro Sarana dan Prasarana danInspektorat. Data sekunder yang digunakan dalam penelitian ini adalah Laporan Hasil Pemeriksaan BPK atas Laporan Keuangan Bakamla Tahun 2016 sampai dengan Tahun 2018. LHP BPK diperoleh dari Pusat Informasi dan Komunikasi BPK RI dengan cara datang langsung dan melengkapi persyaratan berupa surat permohonan tertulis dari Instansi, menunjukkan identitas diri dan melampirkan photocopy identitas diri.

\subsubsection{Instrumen Penelitian}

Wawancara merupakan teknik/cara pengumpulan data dengan melakukan tanya jawab dengan nara sumber yang terkait dengan objek penelitian sedangkan dokumentasi merupakan salah satu teknik/cara pengumpulan data dengan meneliti isi dokumen yang terkait dengan objek penelitian. Dengan demikian, penggunaan teknik dokumentasi dan wawancara dalam pengumpulan data ini dapat memberikan informasi yang lebih banyak dan mendalam mengenai permasalahan yang diteliti. Content analysis dilakukan dengan mengumpulkan semua temuan tertulis. Instrumen penelitian ini adalah wawancara, dokumentasi, dan content analysis, dan Artefacts.

\subsubsection{Analisis Data}

Analisis data dalam penelitian ini dilakukan melalui analisis kualitatif deskriptif (qualitative descriptive analysis), analisis konten (content analysis), dan Analisa tematik (thematic analysis) dengan menggunakan software N-Vivo. Analisis deskriptif dilakukan untuk menggambarkan fenomena menggunakan katakata atau angka-angka dalam mengolah data dan informasi yang berasal dari dokumentasi dan wawancara kemudian menyajikannya untuk menjawab permasalahan penelitian (Cresswell, 2014). Tahapan analisis data dalam penelitian ini yaitu:

1. Mengumpulkan data dan informan yang relevan dengan tujuan penelitian. Melakukan observasi dengan cara wawancara dan mengumpulkan dokumentasi pada bidangbidang yang sangat berpengaruh terhadap pelaporan keuangan Bakamla yaitu; Inspektorat, Biro Sarana dan Prasarana, Biro Umum, dan Biro Perencanaan dan Organisasi.

2. Mereduksi data dengan memilih data yang penting dan memfokuskan pada hal-hal yang pokok.

3. Menyajikan data dalam bentuk alur manajemen tata kelola bidang tertentu yang telah dilakukan oleh Bakamla.

4. Membandingkan dengan standar sehingga dapat dilakukan evaluasi atas penerapan peraturan keuangan.

5. Menarik kesimpulan dari data yang diteliti dan menentukan rule determination sebagai luaran dari studi kasus yang dijalankan dalam penelitian ini.

\section{HASIL PENELITIAN}

Bab ini membahas hasil temuan dan diskusi penelitian untuk menjawab pertanyaan penelitian yang telah disebutkan pada Bab 1 .

4.1. Hasil Temuan-Wawancara dan Laporan Hasil Pemeriksaan BPK atas Laporan Keuangan Bakamla Tahun 2016 s.d 2018

\subsubsection{Wawancara}

Dalam penelitian ini, Wawancara dilakukan terhadap tiga responden. Responden berasal dari Biro Sarana dan Prasarana 3 orang dan Inspektorat 1 orang. Wawancara dilakukan dengan menemui responden secara langsung di Kantor Bakamla. Wawancara dilaksanakan pada kurun waktu Oktober s.d November 2019. Daftar pertanyaan disusun berdasarkan Research Question dan Tujuan Penelitian.

Hasil wawancara kemudian ditranskrip secara manual untuk selanjutnya dilakukan analisis menggunakan software NVivo. Dari content analysis pada menu Word Frequency, setelah proses run terlebih dahulu dilakukan penghapusan pada beberapa kata yang tidak relevan dengan data analisis. Kata-kata tersebut meliputi: "kita", "yang", “itu", “apa". Peneliti menemukan beberapa kata yang paling sering disebutkan oleh responden yaitu "BMN" 59 kali, "aset" 48 kali, "keuangan" 31 kali, "kendala" 23 kali, "laporan" 20 kali, "BPKP" 16 kali, "pengawasan" 15 kali, "pengelolaan" 11 kali, "penyusunan" 10 kali, "barang" 9 kali, "peraturan" 9 kali, dan "BMNnya" 1 kali. Ilustrasi frekuensi kemunculan kata-kata yang diucapkan oleh responden dapat dilihat pada worldcloud seperti yang terdapat pada Gambar 3. 
Gambar 3. Worldcloud Jawaban Responden Sumber: diolah dari data response wawancara menggunakan software $\mathrm{N}$-Vivo di awal tadi, kita ini satu satker dengan banyak PPK di dalamnya" (Responden 2, 2019)

Bakamla merupakan satu satker dengan banyak

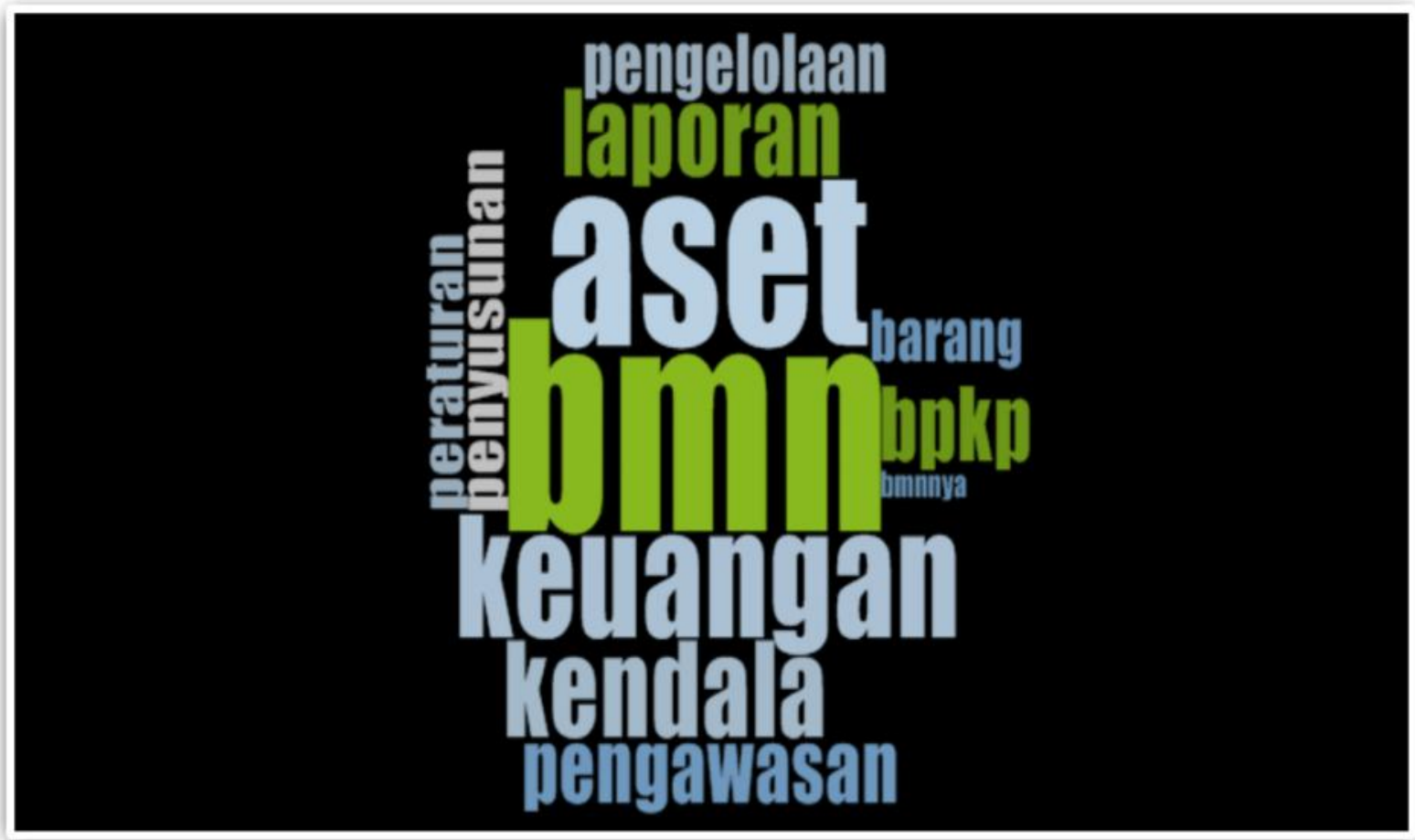

Jika merujuk pada Laporan hasil pemeriksaan BPK atas Laporan Keuangan Bakamla, Barang Milik Negara (BMN) yang meliputi aset tetap, persediaan merupakan temuan yang signifikan berpengaruh pada opini Laporan Keuangan Bakamla. LHP atas Pengendalian Sistem Internal misalnya: BPK menyatakan untuk tahun 2017 dan 2018 Pengelolaan Aset Tetap di Bakamla belum tertib (LHP BPK, 2018 dan 2019). Pembahasan lebih lanjut mengenai Laporan Hasil Pemeriksaan BPK terdapat pada subbagian selanjutnya.

Sejak memperoleh opini TMP pada tahun 2017, Bakamla telah melakukan inventarisasi masalah, misalnya untuk tanah dan bangunan, Bakamla mengajukan Penetapan Status Pengguna (PSP) ke Kementerian Keuangan c.q Direktorat Jenderal Kekayaan Negara. Selanjutnya pada tahun 2018 BPK mengaudit kembali dan hasilnya sama yaitu Opini TMP. Temuan juga hampir sama dengan tahun sebelumnya, meskipun nilai temuan atas aset yang belum jelas keberadaannya berkurang dibanding tahun sebelumnya. Pada tahun 2018, Bakamla melakukan inventarisasi lagi, namun dimulai dari daerah, di mana Bakamla juga memiliki kantor-kantor di daerah dari wilayah barat sampai wilayah timur Indonesia. Hal ini sebagaimana diungkapkan responden 2: “Nah, di 2018 kita lakukan inventarisasi lagi, tapi ini kita mulai dari daerah, bapak tau kan kita punya kantor-kantor juga di daerah dari wilayah barat sampai wilayah timur, itu yang saya sampaikan
PPK di dalamnya. Hasilnya pada tahun 2018, inventarisasi aset di daerah telah selesai dilaksanakan namun belum selesai di pusat karena masih ada renovasi. Oleh karena itu, BPK memberi opini TMP lagi untuk LK tahun 2018, dengan catatan inventarisasi aset baru dilakukan di daerah dan di belum dilakukan di satker pusat.

Pada tahun 2019, Bakamla menertibkan aset kembali. Selanjutnya Bakamla membuat SOP tentang penatausahaan BMN dan diajukan ke Biro Perencanaan (Roren) untuk proses penerbitan menjadi Peraturan Kepala Bakamla.

\subsubsection{Laporan Hasil Pemeriksaan Atas Laporan Keuangan \\ Hasil Pemeriksaan atas Laporan Keuangan Badan Keamana Laut untuk terdiri dari tiga Laporan yaitu: LHP atas Laporan Keuangan, LHP atas Sistem Pengendalian Intern, dan LHP atas Kepatuhan terhadap Peraturan Perundang- undangan. Pada sub bagian ini peneliti akan menyajikan LHP atas Laporan Keuangan Bakamla Tahun 2018.}


Bakamla menyajikan saldo Persediaan per 31 Desember 2018 sebesar Rp15,32 miliar. Pengujian atas saldo Persediaan Tahun 2018 menunjukkan terdapat persediaan sebesar Rp3,66 miliar yang disajikan tidak berdasarkan hasil inventarisasi fisik (stock opname) akhir tahun (LHP BPK, 2019). Catatan dan data yang tersedia tidak memungkinkan BPK melakukan prosedur pemeriksaan yang memadai untuk meyakini persediaan tersebut.

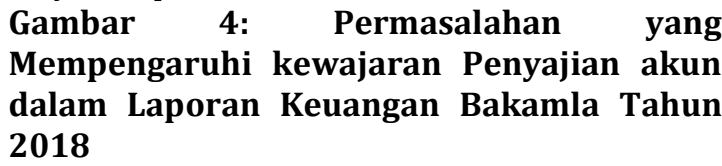

belum jelas keberadaannya (LHP BPK, 2019). Catatan dan data yang tersedia tidak memungkinkan BPK untuk melakukan prosedur pemeriksaan yang memadai untuk meyakini nilai tersebut. Rekapitulasi permasalahan yang mempengaruhi kewajaran Penyajian akun dalam LK Bakamla Tahun 2018 terdapat pada gambar 4 .

\subsubsection{Laporan Hasil Pemeriksaan Sistem Pengendalian Intern}

BPK menemukan kondisi yang dapat dilaporkan
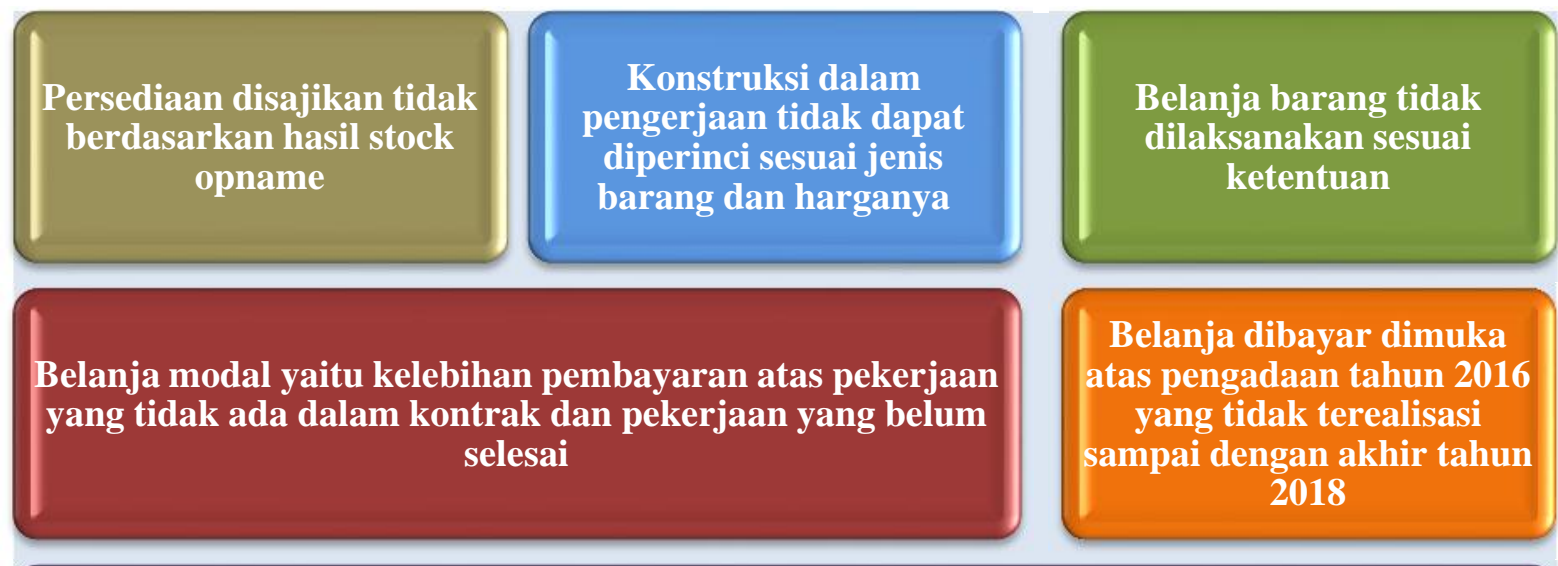

Aset tetap yang berasal dari alih status Kementerian Koordinator Bidang Politik, Hukum dan Kemananan belum jelas keberadaannya

Sumber: LHP BPK Tahun 2018, diolah kembali oleh penulis

Bakamla menyajikan saldo Belanja Dibayar Dimuka dann Konstruksi Dalam Pengerjaan (KDP) per 31 Desember 2018 masing-masing sebesar Rp106,2 miliar dan Rp847,02 miliar. Saldo Belanja Dibayar Dimuka dan KDP tersebut berasal dari realisasi tiga pekerjaan pada Tahun 2016 yang transaksi Keuangan dan perjanjian kontraknya dihentikan oleh KPK (LHP BPK, 2019). Ketidakpastian dampak proses hukum oleh KPK dan Aparat Penegak Hukum lainnya yang masih berlangsung serta KDP yang tidak dapat dirinci sesuai jenis barang dan harganya mengakibatkan BPK tidak dapat melakukan penilaian atas kewajaran saldo Belanja Dibayar Dimuka dari KDP.

Bakamla menyajikan Aset Tetap Peralatan dan Mesin per 31 Desember 2018 sebesar Rp1,34 triliun. Pengujian atas saldo Aset Tetap Peralatan dan Mesin Tahun 2018 menunjukkan terdapat Aset Tetap Peralatan dan Mesin sebesar 57,55 miliar yang berasal dari alih status aset Kementerian Politik, Hukum dan Keamanan, berkaitan dengan sistem pengendalian intern dan operasinya. Pokok-pokok kelemahan dalam sistem pengendalian intern atas Laporan Keuangan Bakamla yang ditemukan BPK antara lain sebagai berikut:

1. Penatausahaan pajak belum memadai dan pertanggungjawaban uang persediaan (UP) tidak lengkap yang mengakibatkan tertundanya penerimaan negara atas pajak yang tidak dipotong/dipungut sebesar Rp85.418.601,88 dan pertanggungjawaban belanja uang persediaan sebesar Rp29.274.840,00 belum dapat diyakini kewajarannya.

Kondisi tersebut terjadi karena:

a. PA/KPA lemah dalam melaksanakan pengawasan pengelolaan Keuangan yang menjadi tanggung jawabnya;

b. Bendahara Pengeluaran belum sepenuhnya memahami ketentuan dalam melaksanakan kewajiban perpajakan dan menatausahakan dokumen perpajakan dan pertanggungjawaban Keuangan; dan 
c. PPSPM tidak mempedomani ketentuan dalam mengujian dokumen pengajuan pembayaran belanja UP maupun LS.

2. Penatausahaan persediaan belum tertib yang mengakibatkan penyajian saldo Persediaan per 31 Desember 2018 senilai Rp3.664.199.170,00 tidak dapat diyakini keandalan dan kewajarannya.

Kondisi tersebut terjadi karena:

a. KPB lemah dalam melaksanakan pengawasan pengelolaan persediaan yang menjadi tanggung jawabnya;

b. Bakamla belum memiliki SOP yang mengatur pelaksanaan pengelolaan dan penatausahaan barang persediaan;

c. Kepala Subbagian Rumah Tangga tidak mempedomanai ketentuan dalam melaksanakan barang persediaan;

d. Operator Persediaan tidak cermat dalam melaksanakan penatausahaan barang persediaan.

3. Penyajian saldo Belanja Dibayar Dimuka tidak sesuai Standar Akuntansi Pemerintahan (SAP) yang mengakibatkan saldo Belanja Dibayar Dimuka senilai Rp87.257.669.877,00 belum dapat diyakini kewajarannya. Kondisi tersebut terjadi karena Kepala Subbagian Akuntansi dan Kepala Bagian Keuangan kurang cermat dalam meneliti dan menganalisis Laporan Keuangan.

Berdasarkan kelemahan tersebut, BPK merekomendasikan Kepada Bakamla antara lain agar:

1. Memperingatkan KPA untuk meningkatkan pengendalian pelaksanaan anggaran dan pengawasan pengelolaan Keuangan yang menjadi tanggung jawabnya;

2. Memerintahkan Bendahara Pengeluaran untuk:

a. Memungut dan menyetorkan ke Kas Negara atas belanja yang kurang atau belum dipungut pajak serta mempertanggungjawabkan

pemungutan pajak yang belum dilengkapi SSP;

b. Mempertanggungjawabkan belanja melalui mekanisme Uang Persediaan (UP) yang belum dilengkapi bukti dan jika tidak dapat dipertanggungjawabkan agar disetor ke Kas Negara; dan

c. Mencatat dan menyajikan Laporan pemungutan dan penyetoran pajak secara berkala dan melalui Buku Pembantu Pajak.

3. Memperingatkan KPB untuk meningkatkan pengawasan pengelolaan persediaan yang menjadi tanggung jawabnya;

4. Memerintahkan Sekretaris Utama untuk menyusun Kebijakan dan Prosedur pengelolaan dan penatausahaan barang persediaan.

4.1.4. LHP atas Kepatuhan Terhadap Peraturan Perundang-undangan

Rekapitulasi Kelemahan SPI dan Ketidakpatuhan terhadap Ketentuan Peraturan Perundang-undangan Badan Keamanan Laut Tahun 2018 dilihat pada lampiran 1 Penelitian ini.

\subsection{Diskusi}

Fenomena dalam permasalahan penelitian ini telah disimpulkan dari beberapa yang berasal dari Inspektorat (Responden 1) dan Biro Sarana dan Prasarana (Responden 2 dan 3).

\subsubsection{Tingkat Kesamaan Bakamla dan Institusi-institusi lainnya dalam pengungkapan Laporan Keuangan/Symbolic Carriers}

Teori institusional dapat mengungkap apakah suatu organisasi benar-benar solid (highly coupled) atau suatu organisasi tampak solid tapi sebenarnya hanya semu (decoupled). Setiap organisasi memiliki aturan (rule) yang ditetapkan. Pada kasus ini, aturan itu ditetapkan oleh pemerintah pusat dan diturunkan dalam bentuk SOP sebagai pedoman pelaksanaan di lingkungannya. Pada kenyataannya, Bakamla menghadapi berbagai kendala yang menyebabkan terjadinya perbedaan antara aturan dengan kegiatan sehari-hari yang dilaksanakan (routines). Terdapat beberapa perilaku decoupling yang ditemukan oleh peneliti berdasarkan research question ke-1 melalui wawancara yang dilakukan, yakni sebagai berikut.

Pertama, pemahaman terhadap peraturan belum menyeluruh dan sinergis antar aktoraktor yang berperan dalam hal pelaporan keuangan. Hal ini menjadi kendala pokok dalam menjalankan peraturan apalagi merumuskan SOP keuangan dan asset sesuai keunikan Bakamla. Hal ini jelas disampaikan oleh responden kedua:

"ya sebenarnya itu kendala utama atau dominan di kita. Jadi begini mas, sebenarnya kita di level staf sampai eselon 4 udah oke nih, udah klop dan faham mengenai kerjaan kita, aturan-aturan mengenai pengelolaan aset, Cuma ya ketika masuk ke level yang lebih tinggi (eselon 4, eselon 3 , dan seterusnya) sering kali aturan-aturan itu tidak dilaksanakan sebagaimana mestinya, kita sudah beritahu tapi mereka terkadang ikut aturan atau kebiasaan dari unit asal (TNI). Jadi seperti piramida ya pak, makin ke atas itu 
rasanya makin sulit untuk melaksanakan aturannya." (Responden 2, 2019)

"Kita ikut aturan-aturan dari Kemenkeu, kita terapkan di Bakamla, nah cuman kan ada beberapa aturan yang belum kita sesuaikan dengan keunikan di Bakamla. Contoh nih, tentang kebijakan akuntansi aset, persedian, dan sebagainya, kita belum punya, kadang operator SIMAK ya justifikasi sendiri, atau hebatnya lagi itu ga diapa-apain" (Responden 2, 2019)

Kedua, rendahnya pengelolaan data kinerja dikarenakan ketersediaan dan validitas data keuangan dan asset sangat bergantung pada petugas pengelola data bukan pada system pengelolaannya dengan alasan perpindahan tugas/mutasi petugas keuangan yang terlalu cepat mempengaruhi ketersediaan data asset. Dalam suatu organisasi, seharusnya proses perpindahan pegawai tidak mengganggu proses pengelolaan data kinerja. Hal ini diungkapkan oleh responden kedua:

"Begini pak, kalau terkait Laporan dari aset kan hampir sama dengan yang dikerjakan dibagian Keuangan, data-data dari aset nanti digabung dengan bagian Keuangan. Kendala kita itu dari bentuk organisasi kita mas. Kita itu 1 satker dengan banyak PPK (Pejabat Pembuat Komitmen) yang tersebar di pusat dan juga daerah. Terbayangkan bagaimana ribetnya kita kompilasi Laporan dari masing-masing PPK. Ditambah lagi terkadang ada PPK yang tidak melaksanakan tugasnya dengan baik, PPK tidak paham tahapan proses secara keseluruhan." (Responden 2, 2019)

"Kendala kedua ya seperti bapak singgung kemarin mengenai Institutional logics, model organisasi kita, pejabatnya cepet banget ganti. ya sebenarnya itu sih kendala utama atau dominan di kita. Pejabat kita itu pak cepet banget gantinya. Sebagian besar dari TNI (Angkatan Laut). Pejabat (eselon 3) itu masuk, kita kadang diskusi, saling share lah, eh baru sebentar udah ganti lagi...." (Responden 2, 2019)

"Anehnya setiap kami meminta penjelasan atau pertanggungjawaban semua menanggapi 'cari aman' karena sebentar lagi juga mutasi. Jadi semacam lepas tangan gitu". (Responden 3, 2019)

Ketiga, keunikan struktur Bakamla yang berasal dari beberapa instansi yang berbeda (TNI/POLRI, KKP, Kemenkum dan HAM dan Pemda) masih menjadi sumbangsih terbesar dalam permasalahan ini terkait penyusunan laporan keuangan Bakamla. Setiap aktor yang terlibat dalam laporan keuangan masih menggunakan kebiasaan-kebiasaan di unit asalnya padahal hal tersebut bertentangan dengan aturan yang ditetapkan Kementerian Keuangan. Hal ini diungkapkan oleh responden pertama dan kedua:
"PPK kita rata-rata berasal dari TNI mendapat ditugaskan di Bakamla. Kadang-kadang mereka juga ikut pola aturan atau kebiasaan-kebiasaan di unit asalnya yang terkadang ga sesuai sama aturan yang ada yang dikeluarkan oleh Kemenkeu." (Responden 2, 2019)

"Kita inspektorat belum punya SOP, ini baru mulai digalakkan. Jadi selama ini ya jalan aja, ya BAU lah (Business As Usual). Jadi selama ini panduan kita dari Pejabat yang datang, jadi misal Pejabat dari polisi, ya kita ikut pengalaman Pejabat itu di instansi asalnya. Selama ini kami bersama BPKP aja, BPKP bantu tugas-tugas inspektorat untuk membantu memperbaiki temuan-temuan BPK itu. Saat ini ada 4 orang pegawai BPKP yang membantu kita." (Responden 1, 2019)

Berdasarkan hasil wawancara di atas, dapat teridentifikasi terjadinya decoupling, yaitu: Keunikan struktur Bakamla yang berasal dari beberapa instansi yang berbeda (TNI/POLRI, KKP, Kemenkum dan HAM dan Pemda) masih menjadi sumbangsih terbesar dalam permasalahan ini terkait penyusunan laporan keuangan Bakamla, pemahaman terhadap peraturan belum menyeluruh dan sinergis antar aktor-aktor yang berperan dalam hal pelaporan keuangan, ketersediaan dan validitas data keuangan dan asset sangat bergantung pada petugas pengelola data bukan pada system pengelolaannya.

Teori institusional mampu menjelaskan fenomena yang terjadi di Bakamla dalam hal pelaporan keuangan dan aset sehingga pada sub-bab ini telah menjawab pertanyaan penelitian $1 \mathrm{a}, 1 \mathrm{~b}$, dan $1 \mathrm{c}$ sebagaimana terdapat pada Tabel 1 .

\subsubsection{Faktor Institusional yang memfasilitasi atau mencegah material carrier dipisahkan dari Symbolic Carrier/Decoupled}

Rendahnya evaluasi terhadap seluruh kegiatan yang diikuti atau yang diselenggarakan oleh Bakamla. Suatu organisasi cenderung melakukan tindakan seremonial dan ritual yang secara simbolis mengadopsi norma-norma dan ketentuan institusional dengan menyembunyikan fakta bahwa organisasi sebenarnya tidak bermaksud untuk menjalankannya (Meyer dan Rowan, 1977). Inkonsistensi terjadi karena keinginan Bakamla untuk mencapai visi dan misi menurut aturanaturan yang berlaku (Symbolic Carrier) tidak sesuai dengan pelaksanaannya (decoupled). Hal ini terlihat dari ungkapan responden kedua:

"Terakhir kali, saya ikut pelatihan di Purnawarman BPPK di tahun ini juga (2019). Nah, setelah ikut pelatihan kan biasanya kita lakukan knowledge sharing, lalu kita mengumpulkan staf, Pejabat (eselon 4, eselon 3), lalu kita sampaikan materi-materi yang kita 
dapat saat pelatihan, tapi ter kadang eselon 3 begitu aja, balik lagi ikut kebiasan-kebiasan di unit asalnya. Kadang dibalik, yang ikut pelatihan middle managementnya (eselon 3) setelah itu mereka menyampaikan knowledge sharing, tapi ya lagi-lagi, kadang apa yang disampaikan tidak sesuai dengan tema diklat/pelatihan yang diikuti.. "(Responden 2, 2019)

"Kami pernah meminta bimbingan dan penjelasan perihal LK sebelum kami menjabat kepada SDM yang dulunya menjabat namun sudah mutasi, namun mereka enggan menjelaskan dan anehnya malah menyuruh buat saja seperti biasa". (Responden 3, 2019)

4.2.3. Tingkat Kesamaan Bakamla dan Institusi-institusi lainnya atas tekanantekanan isomorfis baik yang berasal dari dalam maupun luar institusi / Isomorphism

Suatu organisasi cenderung kurang rasional karena keterbatasan pilihan-pilihan yang lebih efisien yang dapat diambil (DiMaggio and Powell, 1983). Hal ini merupakan bentuk dari isomorphism. Isomorphism dilakukan oleh organisasi untuk menyesuaikan diri dengan lingkungan kelembagaan organisasi. Bentukbentuk isomorphism yang terjadi di Bakamla adalah sebagai berikut:

\subsubsection{Coersive Isomorphism}

Coersive Isomorphism terjadi ketika suatu organisasi merubah aturan sebagai respon dalam menghadapi tekanan formal maupun informal dari lingkungan kelembagaannya. Coersive Isomorphism terjadi di Bakamla menurut responden pertama:

"Saya coba bandingkan dengan teman saya di Inspektorat di kementerian lain, dia itu berani untuk mengatakan ini tidak bisa dipertanggungjawabkan, kembalikan uangnya, nah dikita ini belum bisa setegas itu. Hanya memberikan semacam rekomendasi, saran, atau catatan. Nah kita juga belum punya sistem pengendalian internal." (Responden 1, 2019)

\subsubsection{Mimetic Isomorphism}

Mimetic Isomorphism terjadi saat para aktor menghadapi situasi yang tidak pasti sehingga memutuskan untuk meniru praktikpraktik yang telah dilaksanakan oleh organisasi lain yang dianggap lebih baik dengan tujuan untuk mencapai legitimasi. Dalam kasus ini, Bakamla meniru lembaga lain (tidak disebutkan) dalam menegakkan aturan keuangan dan aset secara mandiri seperti yang dilakukan oleh responden pertama dan kedua:

"Kalau bicara peran Inspektorat itu yang saya fahami ya memberikan review kemudian memberikan assurance. Namun terkadang kembali juga ke Pejabat/pegawai di unit tersebut. Disatu sisi karena inspektorat ini SDMnya belum terpenuhi secara struktural terkhusus auditor, sampai saat ini kita belum punya jabatan fungsional auditor". (Responden 1, 2019)

"Kita sih sebenarnya ingin seperti unit-unit lain yang mungkin modelnya sama seperti kita (organisasi yang awalnya berada di bawah kemenpolhukan yang sebagian besar pejabatnya diemban oleh TNI/Polri). Mereka itu ada Pejabat yang berasal dari BPKP. Jadi sangat membantu pak.

Di Kementerian Kelautan dan Perikanan misalnya, ada itu Pejabat mereka yang berasal dari BPKP. Jadi bisa betul-betul membantu dalam hal Keuangan dan pengelolaan BMN/asset". (Responden 2, 2019)

\subsubsection{Normative Isomorphism}

Normative Isomorphism terjadi saat suatu organisasi mengandalkan tenaga professional di bidangnya untuk meningkatkan kemampuan internal organisasi. Usaha Bakamla dalam menjalankan profesionalisme terlihat dari pernyataan responden pertama dan kedua:

"Kita inspektorat belum punya SOP, ini baru mulai digalakkan. Jadi selama ini ya jalan saja, ya BAU lah (Business As Usual). Jadi selama ini ya panduan kita ya dari Pejabat yang datang, jadi misal Pejabat dari polisi, ya kita ikut pengalaman Pejabat itu di instansi asalnya. Selama ini kami sama BPKP aja, BPKP bantu tugas-tugas inspektorat untuk membantu memperbaiki temuan-temuan BPK itu. Saat ini ada 4 orang pegawai BPKP yang bantu kita". (Responden 1, 2019)

"Saya terakhir ikutan pelatihan di purnawarman BPPK di tahun ini juga (2019). Nah, setelah ikut pelatihan kan biasanya kita lakukan knowledge sharing" (Responden 2, 2019)

Kunci utama dari analisis institusional adalah untuk memahami hubungan antara logics dan perubahan institusional yang dilakukan oleh para aktor. Oleh karena itu, menganalisis peran aktor dalam organisasi sangat penting dalam meninjau implementasi new institutional theory yaitu apakah pada akhirnya aktor-aktor dalam organisasi berperilaku dan berproses untuk couple atau decouple karena adanya batasan lingkungan dan kenyataan di lapangan. Berdasarkan hasil wawancara dan temuan yang didapatkan, implementasi Institutional logics dan Isomorphism berperan penting bagi Bakamla dalam memutuskan restrukturisasi SOP keuangan dan asset seperti yang jelas terlihat pada Gambar 5.

Gambar 5 Institutional Logics dan Isomorphism (DiMaggio dan Powell, 1983) dan (Zilber, 2013)

Sumber: (DiMaggio dan Powell, 1983) dan (Zilber, 2013), diolah oleh penulis. 
Berdasarkan hasil temuan yang didapatkan, teori institusional mampu menjelaskan fenomena yang terjadi di Bakamla dalam hal pelaporan keuangan dan asset sehingga penelitian ini dapat menjawab seluruh permasalahan penelitian seperti yang tertera pada Tabel 1. dalam permasalahan ini terkait penyusunan laporan keuangan Bakamla, setiap aktor yang terlibat dalam laporan keuangan masih menggunakan kebiasaankebiasaan di unit asalnya padahal hal tersebut bertentangan dengan aturan yang ditetapkan Kementerian Keuangan.

2) Rendahnya evaluasi terhadap seluruh

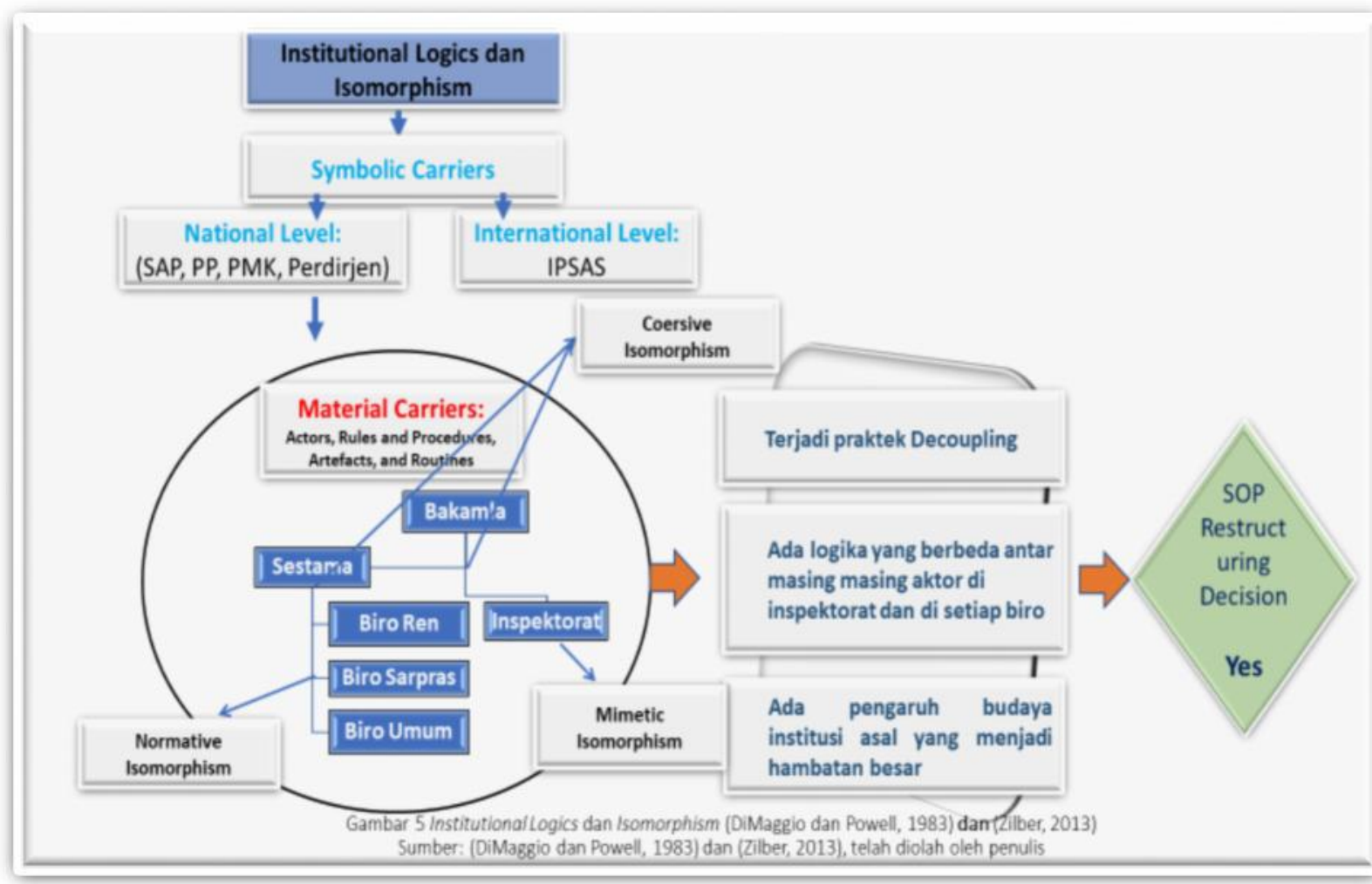

\section{KESIMPULAN DAN SARAN}

Ketiadaan auditor pada Bakamla menjadi indikator utama terjadinya Isomorphism. Pada penelitian ini, Coercive merupakan pendorong utama yang terjadi karena adanya tekanan informal dari eselon 3 dan eselon di atasnya agar aktor menjalankan tugasnya menurut kebiasaan yang mereka bawa dengan mengenyampingkan peraturan yang berlaku.

Mimetic tampak dari pernyataan responden di Bakamla yang meniru lembaga lain (tidak disebutkan) dalam menegakkan aturan keuangan dan asset secara mandiri.

Normative terjadi saat pihak-pihak professional dari BPKP mendampingi Bakamla dalam menyusun laporan keuangan pada tahun 2017 hingga saat ini. Inspektorat juga telah mendelegasikan aktor dari biro sarana dan prasarana untuk mengikuti pelatihan-pelatihan yang diselenggarakan oleh BPPK.

Berbagai kendala teknis maupun non teknis telah menyebabkan terjadinya decoupling, yaitu:

1) Keunikan struktur Bakamla yang berasal dari beberapa instansi yang berbeda (TNI/POLRI, KKP, Kemenkumham, Pemda, dll) masih menjadi sumbangsih terbesar kegiatan yang diikuti atau yang diselenggarakan oleh Bakamla. Inkonsistensi terjadi karena keinginan Bakamla untuk mencapai visi dan misi tidak sesuai dengan pelaksanaannya.

3) Pemahaman terhadap peraturan belum menyeluruh dan sinergis antar aktor-aktor yang berperan dalam hal pelaporan keuangan.

4) Rendahnya pengelolaan data kinerja. Ketersediaan dan validitas data keuangan dan asset sangat bergantung pada petugas pengelola data bukan pada sistem pengelolaannya.

Berdasarkan hasil wawancara dan temuan yang didapatkan, implementasi Institutional logics dan Isomorphism berperan penting bagi Bakamla karena permasalahan keuangan yang terjadi di Bakamla dapat teridentifikasi dengan jelas, serta mampu mengarahkan pada solusi permasalahan yaitu memutuskan restrukturisasi SOP keuangan dan asset. Dikarenakan sifat keunikan Bakamla sehingga para aktor sulit menegakkan aturan-aturan yang berlaku di Kemenkeu, maka perlu dirancang IT System dan Assestment Project sebagai alur 
pengelolaan keuangan dan asset yang secara lengkap diatur dalam SOP Penatausahaan Persediaan dan SOP Tindak Lanjut Hasil Rekomendasi BPK.

Penelitian ini dapat memberikan manfaat besar khususnya bagi Bakamla dan umumnya lembaga lain dikarenakan teori institusional dapat memberikan gambaran jelas dan terarah atas suatu permasalahan suatu organisasi di berbagai bidang untuk selanjutnya merumuskan putusan menuju target yang ingin dicapai. Namun teori institusional akan dirasakan manfaatnya jika organisasi mau memberika informasi yang dibutuhkan secara mendalam dan terbuka. 


\section{Tabel 1. Analisis Konten Berdasarkan Teori Institusional (Matriks Dua Arah)}

\begin{tabular}{|c|c|c|c|}
\hline \multicolumn{2}{|c|}{ Research Questions } & \multirow{2}{*}{$\begin{array}{l}\quad \text { Aspects } \\
\text { Institutional } \\
\text { logics, } \\
\text { Material } \\
\text { Carriers: } \\
\text { Actors, Rules } \\
\text { and } \\
\text { Procedures, } \\
\text { Artefacts, and } \\
\text { Routines }\end{array}$} & Phenomenon \\
\hline $\begin{array}{l}\text { Bagaimana } \\
\text { dengan tingkat } \\
\text { kesamaan } \\
\text { Bakamla dan } \\
\text { institusi-institusi } \\
\text { lainnya dalam } \\
\text { pengungkapan LK } \\
\text { dan apakah ada } \\
\text { logika dominan } \\
\text { yang menyeluruh } \\
\text { (an overarching }\end{array}$ & $\begin{array}{l}\text { Sejauh mana } \\
\text { Bakamla } \\
\text { menerapkan } \\
\text { dan } \\
\text { memenuhi } \\
\text { semua } \\
\text { persyaratan } \\
\text { pembawa } \\
\text { simbolik } \\
\text { (symbolic } \\
\text { carriers)? }\end{array}$ & & $\begin{array}{l}\text { Pemahaman terhadap peraturan belum } \\
\text { menyeluruh dan sinergis antar aktor-aktor yang } \\
\text { berperan dalam hal pelaporan keuangan. Hal ini } \\
\text { menjadi kendala pokok dalam menjalankan } \\
\text { peraturan terutama dalam merumuskan SOP } \\
\text { keuangan dan asset sesuai keunikan Bakamla. }\end{array}$ \\
\hline & $\begin{array}{l}\text { Sejauh mana } \\
\text { pengaruh } \\
\text { faktor lokal } \\
\text { terhadap } \\
\text { praktik } \\
\text { pelaporan } \\
\text { keuangan di } \\
\text { Bakamla? }\end{array}$ & $\begin{array}{l}\text { Institutional } \\
\text { logics, } \\
\text { Material } \\
\text { Carriers: } \\
\text { Actors, Rules } \\
\text { and } \\
\text { Procedures, } \\
\text { Artefacts, and } \\
\text { Routines }\end{array}$ & $\begin{array}{l}\text { Rendahnya pengelolaan data kinerja di Bakamla } \\
\text { dikarenakan ketersediaan dan validitas data } \\
\text { keuangan dan asset di Bakamla sangat bergantung } \\
\text { pada petugas pengelola data bukan pada sistem } \\
\text { pengelolaannya dengan alasan perpindahan } \\
\text { tugas/mutasi petugas keuangan yang terlalu } \\
\text { cepat mempengaruhi ketersediaan data asset. } \\
\text { Dalam suatu organisasi, seharusnya proses } \\
\text { perpindahan pegawai tidak mengganggu proses } \\
\text { pengelolaan data kinerja. }\end{array}$ \\
\hline & $\begin{array}{l}\text { Apakah ada } \\
\text { satu atau } \\
\text { banyak } \\
\text { logika } \\
\text { pelaporan } \\
\text { LK yang } \\
\text { dilakukan } \\
\text { oleh } \\
\text { Bakamla? }\end{array}$ & $\begin{array}{l}\text { Institutional } \\
\text { logics, } \\
\text { Isomorphisms } \\
\text { (Mimetic) }\end{array}$ & $\begin{array}{l}\text { Keunikan struktur Bakamla yang berasal dari } \\
\text { beberapa instansi yang berbeda (TNI/POLRI, KKP, } \\
\text { Kemenkum dan HAM dan Pemda) masih menjadi } \\
\text { sumbangsih terbesar dalam permasalahan ini } \\
\text { terkait penyusunan laporan keuangan Bakamla. } \\
\text { Setiap actor yang terlibat dalam laporan keuangan } \\
\text { masih menggunakan kebiasaan-kebiasaan di unit } \\
\text { asalnya padahal hal tersebut bertentangan } \\
\text { dengan aturan yang ditetapkan Kementerian } \\
\text { Keuangan. }\end{array}$ \\
\hline
\end{tabular}

Identificat ions

Decoupling Institutional logics

\section{Bagaimana dengan faktor institusional, manakah yang memfasilitasi atau mencegah pembawa materi (material carriers) praktik dipisahkan dari pembawa simbolik (symbolic \\ carriers)?}

Rendahnya evaluasi terhadap seluruh kegiatan yang diikuti atau yang diselenggarakan oleh Bakamla terkait knowledge sharing hal keuangan. Suatu organisasi cenderung melakukan tindakan seremonial dan ritual yang secara simbolis mengadopsi norma-norma dan ketentuan institusional dengan menyembunyikan fakta bahwa organisasi sebenarnya tidak bermaksud untuk menjalankannya (Meyer dan Rowan, 1977). Inkonsistensi terjadi karena keinginan Bakamla untuk mencapai visi dan misi tidak sesuai dengan pelaksanaannya.

Bakamla belum mengaktifkan Sistem Pengendalian Internal (SPI) sehingga Bakamla cenderung melanggar aturan sebagai respon dalam menghadapi tekanan informal dari lingkungan kelembagaannya.

Bakamla meniru lembaga lain (tidak disebutkan) dalam menegakkan aturan keuangan dan asset secara mandiri.

Beberapa biro dalam struktur Bakamla telah diikutsertakan dalam pelatihan yang berkaitan dengan tugasnya. Bahkan saat ini Bakamla telah mengundang 4 orang pegawai BPKP untuk membantu dan mendampingi dalam menyusun laporan keuangan berikutnya.

\section{Decoupling}

\section{Decoupling}

Mimetic
Coercive

Mimetic

Normative institusi (mimetic isomorphism coercive isomorphism, atau normative isomporphism)?

Isomorphisms Mimetic, atau Normative) 


\section{IMPLIKASI DAN KETERBATASAN}

Implikasi penelitian ini adalah pembuatan SOP Penatausahaan Persediaan. SOP ini dibuat sebagai petunjuk Satuan Kerja (Satker) di Bakamla dalam pelaksanaan penatausahaan barang persediaan sesuai dengan ketentuan yang berlaku. Hal ini sesuai dengan rekomendasi BPK yang terdapat pada Laporan Hasil Pemeriksaan atas Sistem Pengendalian Internal. BPK merekomendasikan Kepala Bakamla untuk memerintahkan Sekretaris Utama untuk menyusun Kebijakan dan Prosedur pengelolaan dan penatausahaan barang persediaan. Selanjutnya adalah pembuatan SOP Tindak Lanjut Hasil Pemeriksaan BPK. SOP ini digunakan sebagai acuan dalam pelaksanaan tindak lanjut terhadap temuan hasil pemeriksaan Badan Pemeriksa Keuangan (BPK) pada Bakamla agar dapat dilaksanakan secara efektif, efisien dan akuntabel sesuai Peraturan Perundang-undangan yang berlaku.

Peneliti mendapatkan kesulitan dalam hal perijinan, kesediaan aktor, dan waktu pelaksaan wawancara sehingga temuan yang didapatkan belum menyeluruh dan mewakili dari setiap biro-biro yang terkait dalam penyusunan laporan keuangan Bakamla. Merupakan hal yang menarik jika peneliti lainnya yang ingin melaksanakan penelitian kembali di lingkungan Bakamla maka dapat melakukan beberapa perbaikan, yaitu: pertama, dapat melakukan pengembangan penelitian sampai dengan tingkat daerah bukan hanya pusat (untuk inventarisasi aset). Kedua, peneliti selanjutnya dapat melakukan penelitian sejenis pada lembaga lainnya untuk dapat dieksplorasi lebih mendalam. Selain itu, karakteristik yang berbeda-beda pada tiap instansi pemerintah akan menghasilkan temuan yang berbeda pula.

\section{REFERENSI}

Aldemir, C., \& Uysal, T. U. (2017). Public accounting reform from institutional theory perpectives: case of Turkey. Turki: Intech.

Antaranews. (2013). Bakorkamla berubah menjadi Bakamla. Diakses pada 4 Desember 2019, dari https://www.antaranews.com/berita/411 736/bakorkamla-berubah-menjadi bakamla

Badan Pemeriksa Keuangan. (2017). Laporan Hasil Pemeriksaan Badan Pemeriksa Keuangan atas Laporan Keuangan Badan Keamanan Laut RI Tahun 2016. Diakses pada 20 Oktober 2019, dari www.bpk.go.id.

Badan Pemeriksa Keuangan. (2018). Laporan Hasil Pemeriksaan Badan Pemeriksa Keuangan atas Laporan Keuangan Badan Keamanan Laut RI Tahun 2017. Diakses pada 20 Oktober 2019, dari www.bpk.go.id.
Badan Pemeriksa Keuangan. (2019). Laporan hasil pemeriksaan badan pemeriksa keuangan atas laporan keuangan badan keamanan laut ri tahun 2018. Diakses pada 20 Oktober 2019, dari www.bpk.go.id.

Badan Pemeriksa Keuangan. (2019). Ikhtisar hasil pemeriksaan semester I tahun 2019 badan pemeriksa keuangan atas laporan keuangan badan keamanan laut ri tahun 2018. Diakses pada 20 Oktober 2019, dari www.bpk.go.id.

Badan Keamanan Laut Republik Indonesia. (2019).Visi dan misi bakamla. Diakses pada 20 Oktober 2019, dari https://Bakamla.go.id/home/visi_misi

Carpenter, V. L. \& Feroz, V. H. (2001). Institutional theory and accounting rule choice: an analysis of four us state governments' decision to adopt generally accepted accounting principles. Accounting, Organizations and Society 26, 565-596.

Church, R. M. (2001). The effective use of secondary data. Learning and Motivation $33,32-45$.

Cornelissen, J. P., Durand, R., Fiss, P. C., Lammers, J. C., dan E. Vaara. (2015). Putting communication front and center in institutional theory and analysis. Academy of Management Review, Vol. 40, No.1, 10-27.

Creswell, J. W. (2014). Research design qualitative, quantitative, and mixed methods approaches fourth edition. California: SAGE Publications, Inc.

DiMaggio, P. J., dan W. W. Powell. (1983). Institutional isomorphism and collective rationality in organizational fields. American Sociological Review, Vol. 48, No. 2, 147-160.

DiMaggio, P. J., dan Powell, W. W. (1991). The iron cage revisited: institutional isomorphism and collective rationality. in w. w. powell and p. j. dimaggio.eds., the new institutionalism in organizational analysis. Chicago: University of Chicago Press Originally published. 1983., American Sociological Review. Vol 38, page 147-160.

DiMaggio, P. J., \& Powell, W. W. (Eds.). (1991). The new institutionalism in organizational analysis (Vol. 17). Chicago, IL: University of Chicago Press.

Ellet, W. (2009). Case Study Handbook. In Harvard Business School Press.

Fogarty, T. J. (1996). The imagery and reality of peer review in the us: insight from institutional theory. Accounting, Organizations and Society, 21(2-3), hal. 243-267.

Fuenfschilling, L., dan B. Truffer. (2014). The structuration of socio technical regimes - 
conceptual foundations from institutional theory. Research Policy, 772-791.

Gawer, A., dan N. Phillips. (2013). Institutional work as logics shift: the case of intel's transformation to platform leader. Organization Studies, 1-37.

Greenwood, R., dan R. Suddaby. (2006). Institutional entrepreneurship in mature fields: the big five accounting firms. Academy of Management Journal, Vol. 49, No. 1, 27-48.

Inspektorat Jenderal Kementerian Keuangan. (2019). Diakses pada 18 Oktober 2019, dari http://www.itjen.kemenkeu.go.id/baca/5 70

Kuntadi, C. 2019. Audit internal sektor publik. Jakarta: Salemba Empat.

Lawrence, T., Suddaby, R., dan B. Leca. (2011). Institutional work: refocusing institutional studies of organization. Journal of Management Inquiry 20 (I), 52-58.

Moghaddam, A. G., et.al. (2016). Investigating the relationship between audit opinion and earnings persistence of listed firms in tehran stock exchange. Science Arena Publications Specialty Journal of Accounting and Economics, Vol. 2(1):71-76.

Meyer, R. E., dan M. A. Hollerer. (2014). Does institutional theory need redirecting? Journal of Management Studies 51:7, 12211233.

Oliver, C. (1991). Strategic Response to Institutional Processes. Academy of Management Review No. 1, 145-179.

Pemerintah Republik Indonesia. (2010). Peraturan Pemerintah Nomor 71 tahun 2010 tentang Sistem Akuntansi Pemerintahan.

Reay, T., dan C. Hinings. (2009). Managing the rivalry of competing institutional logics. Organization Studies 30 (06), 629-652.

Republika. (2016). Dicky Munaf, Sestama Badan Keamanan Laut: pengamanan dan keselamatan laut harus berimbang. Diakses pada 4 Desember 2019, dari https://www.republika.co.id/berita/koran /wawasan/16/01/27/o1lt0h5-dickymunaf-sestama-badan-keamanan-lautpengamanan-dan-keselamatan-lautseimbang 


\section{Lampiran}

Rekapitulasi Kelemahan SPI dan Ketidakpatuhan terhadap Ketentuan Peraturan Perundang-undangan Badan Keamanan Laut Tahun 2018 (Nilai dalam Rp Juta)

\begin{tabular}{|c|c|c|c|c|c|c|c|c|c|c|}
\hline \multirow{3}{*}{$\begin{array}{l}\text { Jumla } \\
\text { h } \\
\text { Temu } \\
\text { an }\end{array}$} & \multirow{3}{*}{$\begin{array}{l}\text { Jumlah } \\
\text { Rekomen } \\
\text { dasi }\end{array}$} & \multicolumn{4}{|c|}{ Kelemahan Sistem Pengendalian Intern } & \multicolumn{5}{|c|}{$\begin{array}{l}\text { Ketidakpatuhan terhadap Ketentuan Peraturan Perundang- } \\
\text { undangan yang berlaku }\end{array}$} \\
\hline & & Total & $\begin{array}{l}\text { Kelemahan } \\
\text { Sistem } \\
\text { Pengendali } \\
\text { an } \\
\text { Akuntansi } \\
\text { dan } \\
\text { Pelaporan }\end{array}$ & $\begin{array}{l}\text { Kelemahan } \\
\text { Sistem } \\
\text { Pengendali } \\
\text { an } \\
\text { Pelaksanaa } \\
\text { n } \\
\text { Anggaran } \\
\text { Pendapata } \\
\text { n dan } \\
\text { Belanja }\end{array}$ & $\begin{array}{l}\text { Kelemahan } \\
\text { Struktur } \\
\text { Pengendal } \\
\text { ian Intern }\end{array}$ & Total & Kerugian & $\begin{array}{l}\text { Kekurangar } \\
\text { Penerimaar }\end{array}$ & & $\begin{array}{l}\text { Administr } \\
\text { asi }\end{array}$ \\
\hline & & $\begin{array}{l}\text { Jumlah } \\
\text { Permasala } \\
\text { han }\end{array}$ & $\begin{array}{l}\text { Jumlah } \\
\text { Permasala } \\
\text { han }\end{array}$ & $\begin{array}{l}\text { Jumlah } \\
\text { Permasala } \\
\text { han }\end{array}$ & $\begin{array}{l}\text { Jumlah } \\
\text { Permasala } \\
\text { han }\end{array}$ & $\begin{array}{l}\text { Jumlah } \\
\text { Permasala } \\
\text { han }\end{array}$ & $\begin{array}{l}\text { Nilai } \\
\text { (jutaan) }\end{array}$ & $\begin{array}{l}\text { Jumlah } \\
\text { Permasala } \\
\text { han }\end{array}$ & $\begin{array}{l}\text { Nilai } \\
\text { (jutaan) }\end{array}$ & $\begin{array}{l}\text { Jumlah } \\
\text { Permasala } \\
\text { han }\end{array}$ \\
\hline 18 & 61 & 6 & 4 & 2 & - & 22 & $\begin{array}{l}139.947, \\
44\end{array}$ & 6 & $\begin{array}{l}117.322 \\
48\end{array}$ & 10 \\
\hline
\end{tabular}

Sumber: IHPS BPK, 2019 